\title{
The Yukon Flats Cretaceous(?)-Tertiary Extensional Basin, East-Central Alaska: Burial and Thermal History Modeling
}

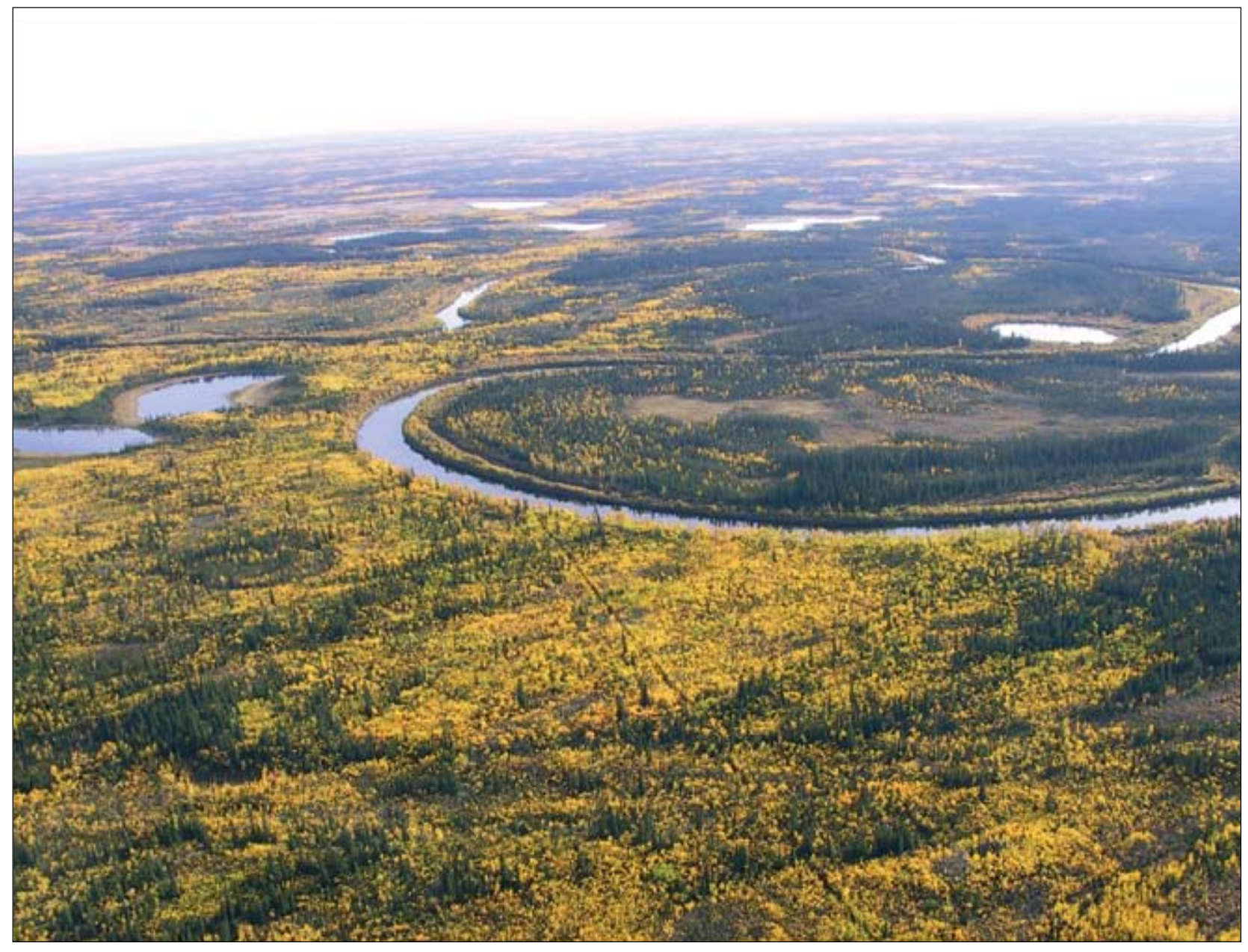

Scientific Investigations Report 2007-5281 
Cover photograph: View of Yukon Flats from the air about 40 miles west of Fort Yukon, Alaska, photographed by Richard G. Stanley, September 3, 2002. The view is to the southwest and shows rivers, lakes, and early fall foliage. The prominent, dark diagonal line in the foreground is a remnant of a seismic reflection survey conducted by the oil industry in 1972. 


\section{The Yukon Flats Cretaceous(?)-Tertiary Extensional Basin, East-Central Alaska: Burial and Thermal History Modeling}

By Elisabeth L. Rowan and Richard G. Stanley

Scientific Investigations Report 2007-5281 


\section{U.S. Department of the Interior DIRK KEMPTHORNE, Secretary \\ U.S. Geological Survey \\ Mark Myers, Director}

\section{U.S. Geological Survey, Reston, Virginia: 2008}

For product and ordering information:

World Wide Web: http://www.usgs.gov/pubprod

Telephone: 1-888-ASK-USGS

For more information on the USGS--the Federal source for science about the Earth, its natural and living resources, natural hazards, and the environment:

World Wide Web: http://www.usgs.gov

Telephone: 1-888-ASK-USGS

Suggested citation:

Rowan, E.L., Stanley, R.G., 2008, The Yukon Flats Cretaceous(?)-Tertiary extensional basin, east-central Alaska: Burial and thermal history modeling: U.S. Geological Survey Scientific Investigations Report 2007-5281, 12 p., available only online at http://pubs.usgs.gov/sir/2007/5281.

Any use of trade, product, or firm names is for descriptive purposes only and does not imply endorsement by the U.S. Government.

Although this report is in the public domain, permission must be secured from the individual copyright owners to reproduce any copyrighted materials contained within this report. 


\section{Contents}

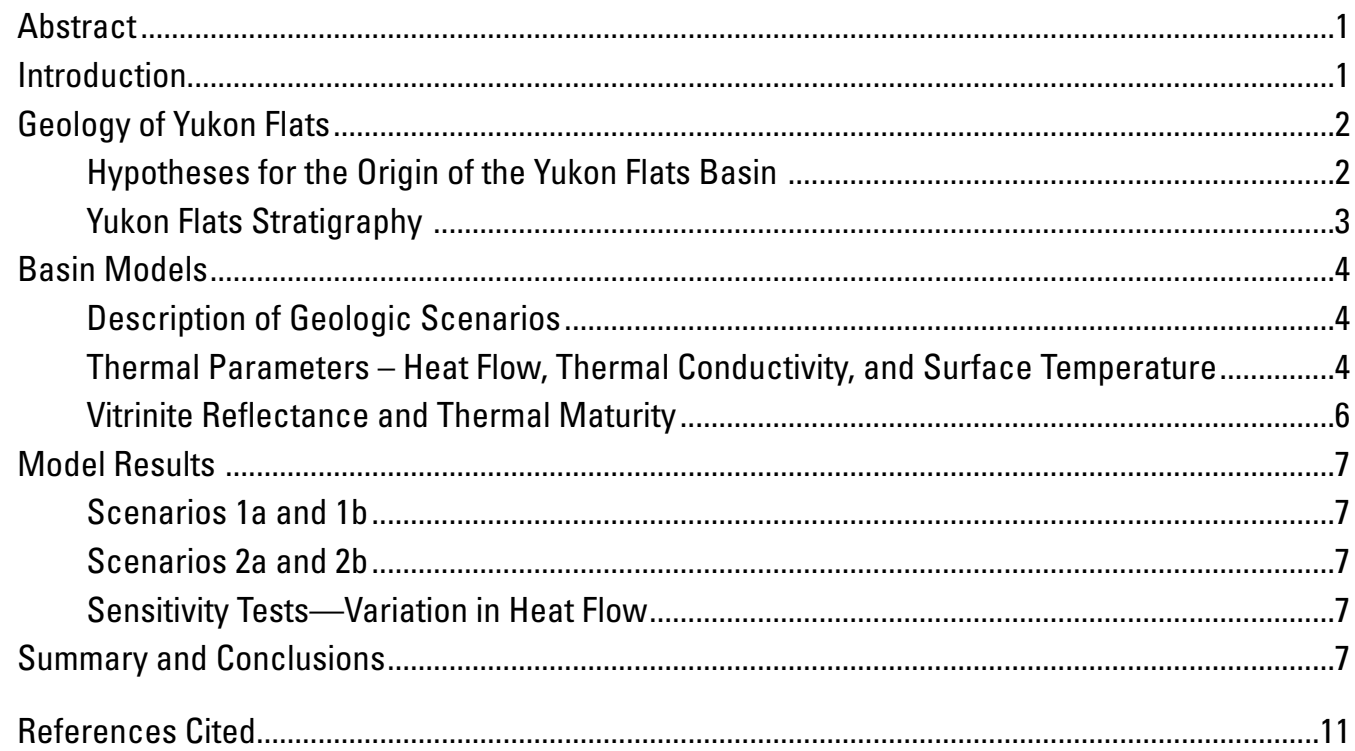

\section{Figures}

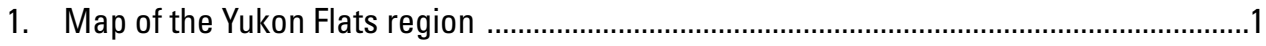

2. Generalized geologic map of the Yukon Flats region .......................................................

3. Schematic geologic cross section through the Yukon Flats basin ....................................

4. Bulk (rock + water) vertical thermal conductivity versus depth, shown for

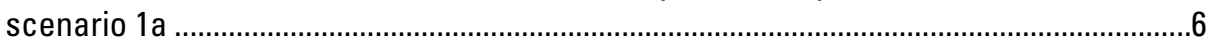

5. Mean annual surface temperature through time at a latitude of $66.5^{\circ} \mathrm{N}$..........................6

6. Burial histories for scenarios $1 \mathrm{a}$ and $1 \mathrm{~b}$, shown in parts $A$ and $B$, respectively,

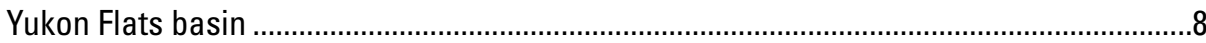

7. Burial histories for scenarios $2 a$ and $2 b$, shown in parts $A$ and $B$, respectively,

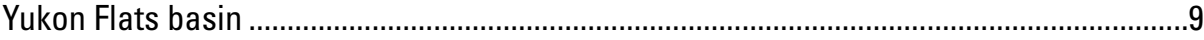

8. Model-calculated vitrinite reflectance $\left(R_{0}\right)$ values for scenario $1 \mathrm{a}$..................................10

9. $\mathrm{R}_{0}$ calculated for a range of heat-flows at the top of the middle-early

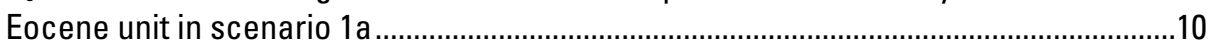

10. Depth to the top of the oil window shown for a range of heat-flow values in scenario $1 \mathrm{a}$

\section{Tables}

1. Hypothetical lithologies and source rocks of the Yukon Flats basin . .4

2. Model units, present day thicknesses, ages, and simplified lithologic compositions used in the Yukon Flats models. 


\section{Conversion Factors}

Inch/Pound to SI
\begin{tabular}{|l|c|c|}
\hline \multicolumn{1}{|c|}{ Multiply } & By & To obtain \\
\hline & Length & meter $(\mathrm{m})$ \\
\hline foot $(\mathrm{ft})$ & 0.3048 & cubic meter $\left(\mathrm{m}^{3}\right)$ \\
\hline & Volume & cubic meter $\left(\mathrm{m}^{3}\right)$ \\
\hline barrel $(\mathrm{bbl}),($ petroleum, 1 barrel=42 gal) & 0.1590 & 0.02832 \\
\hline cubic foot $\left(\mathrm{ft}^{3}\right)$ & &
\end{tabular}

Temperature in degrees Celsius $\left({ }^{\circ} \mathrm{C}\right)$ may be converted to degrees Fahrenheit $\left({ }^{\circ} \mathrm{F}\right)$ as follows: ${ }^{\circ} \mathrm{F}=\left(1.8 \times{ }^{\circ} \mathrm{C}\right)+32$

Temperature in degrees Fahrenheit $\left({ }^{\circ} \mathrm{F}\right)$ may be converted to degrees Celsius $\left({ }^{\circ} \mathrm{C}\right)$ as follows: ${ }^{\circ} \mathrm{C}=\left({ }^{\circ} \mathrm{F}-32\right) / 1.8$ 


\title{
The Yukon Flats Cretaceous(?)-Tertiary Extensional Basin, East-Central Alaska: Burial and Thermal History Modeling
}

\author{
By Elisabeth L. Rowan and Richard G. Stanley
}

\begin{abstract}
One-dimensional burial and thermal history modeling of the Yukon Flats basin, east-central Alaska, was conducted as part of an assessment of the region's undiscovered oil and gas resources. No deep exploratory wells have been drilled in the Yukon Flats region, and the subsurface geology of the basin is inferred from seismic reflection, gravity and magnetic surveys, and studies of shallow core holes in the basin and outcrops in the surrounding region. A thick sequence of Upper Cretaceous(?) and Cenozoic nonmarine sedimentary rocks is believed to fill the basin; coal and organic-rich mudstone and shale within this sequence represent potential hydrocarbon source rocks. The burial and thermal history models presented here represent the sole source of information on the thermal maturity of these potential source rocks at depth.

We present four alternative burial history scenarios for a hypothetical well through the deepest portion of Yukon Flats
\end{abstract}

basin. They differ from each other in the thicknesses of Upper Cretaceous and Cenozoic strata, the timing of initial basin subsidence, and the timing of inferred unconformities. The burial modeling results suggest a present-day depth to the oil window of approximately 6,000 feet.

\section{Introduction}

Yukon Flats is a broad lowland that straddles the Yukon River in east-central Alaska (fig. 1). Although the region is sparsely populated, it includes about a dozen villages, the largest of which is Fort Yukon (population $~ 600$ ). The Trans-Alaska Pipeline System passes to the west of the Yukon Flats basin. The area is remote and mostly roadless; access is primarily by air and by boat.

At present, there is no commercial petroleum production in the Yukon Flats region, and residents import diesel fuel

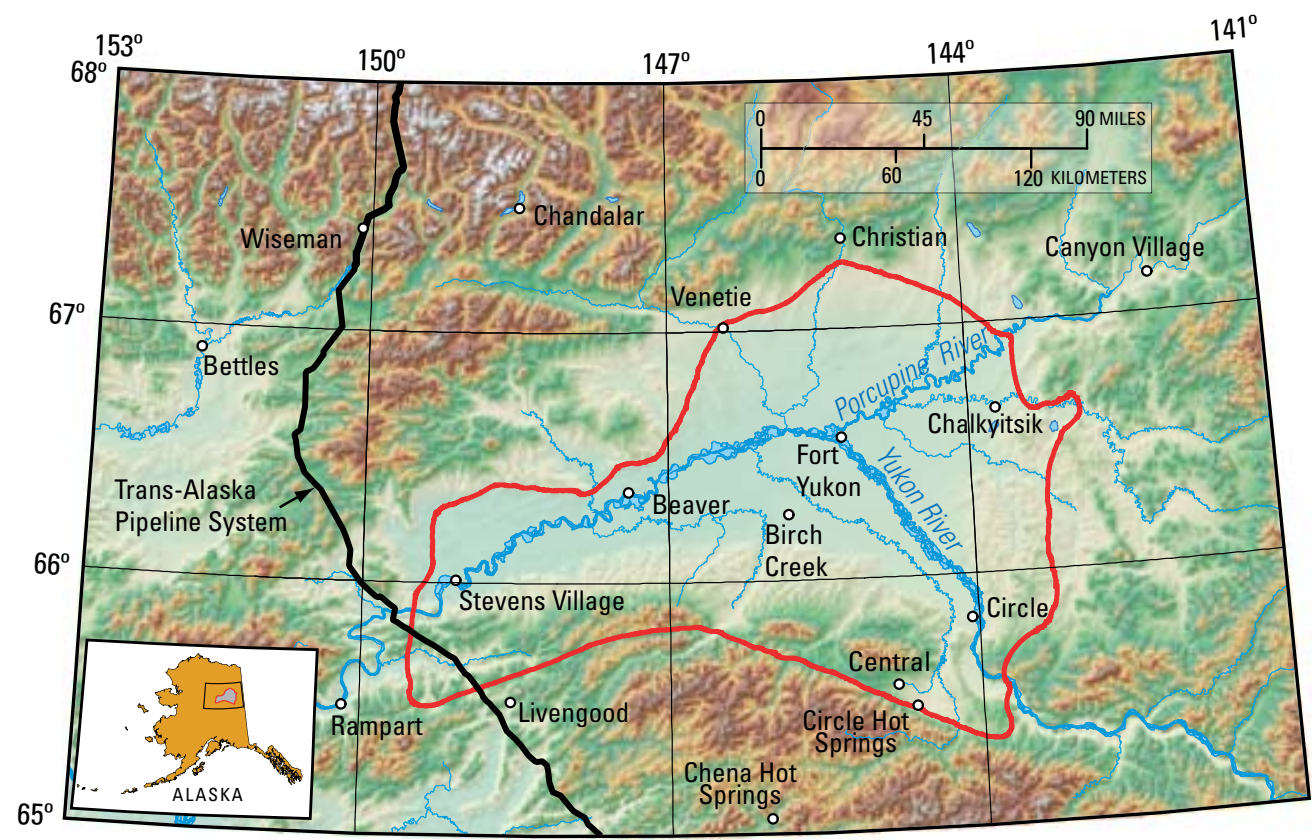

Base from U.S. Geological Survey 1:250,000-scale Wiseman, 1956, (revised 1983); Chandalar, 1956, (limited revisions 1982); Christian, 1956, (limited revisions 1983); Coleen, 1956, (limited revisions 1983) Bettles, 1956 (limited revision 1984); Beaver, 1956, (limited revision 1984); Fort Yukon, 1956, (minor revision 1994); Black River 1956, (limited revision 1984); Tanana, 1960 (limited revision 1984); Livengood 1956, (limited revision 1984); Circle, 1955, (minor revisions 1967); Charley River, 1956, (limited revisions 1982);
Digital Elevation Models (DEMs); Alaska Albers Equal Area Conic projection; 1927 North American Datum
Figure 1. Map of the Yukon Flats region. The red line indicates the approximate boundary of the Yukon Flats basin, as defined for an assessment of undiscovered oil and gas resources (from Stanley and others, 2004). 
and heating oil to meet their energy needs (Finzel and others, 2006). However, an assessment of undiscovered oil and gas resources by the U.S. Geological Survey concluded that significant quantities of technically recoverable oil (estimated mean $\sim 173$ million barrels of oil, MMBO) and gas (estimated mean $\sim 5.5$ trillion cubic feet of gas, TCFG) may be present in the Yukon Flats basin (Stanley and others, 2004). The onedimensional burial and thermal history models presented here were undertaken in conjunction with this assessment to determine whether potential petroleum source rocks have sufficient thermal maturity to have generated oil and (or) gas.

Drilling in the Yukon Flats area is limited to shallow wells located near Fort Yukon (figs. 2 and 3). In 1954, the U.S. Army Corps of Engineers drilled a well to a total depth of 440 feet (ft), intersecting Pleistocene or Tertiary lacustrine(?) silt and silty sand (Williams, 1962). In 1994, the U.S. Geological Survey drilled a well nearby to a total depth of $1,281 \mathrm{ft}$ (Ager, 1994). The well intersected lignite-bearing strata of Miocene age below 1,000 ft. In 2004, this hole was deepened to $2,287 \mathrm{ft}$; preliminary results of the core logging are summarized by Barker and others (2005) and Finzel and others (2006). In the absence of drill hole information from deeper than $\sim 2,300 \mathrm{ft}$, most of the basin's subsurface geology has been inferred from seismic reflection profiles, gravity and magnetic surveys, and geological studies of shallow core holes in the basin and outcrops in the surrounding region.

The only thermal maturity data currently available from the subsurface Yukon Flats basin are vitrinite reflectance measurements made on samples of lignite-bearing strata of Miocene age from the core hole at Fort Yukon. To address the thermal maturity of Tertiary strata at greater depths, burial history models are constructed for a hypothetical deep well located in the deepest part of the Yukon Flats basin (fig. 3) and four alternative geologic scenarios are considered. The model results provide estimated thermal maturities of potential oil and gas source rocks at depth in the basin. The results of this study supersede preliminary results presented in Rowan and Stanley (2005).

\section{Geology of Yukon Flats}

\section{Hypotheses for the Origin of the Yukon Flats Basin}

Several mechanisms have been proposed to explain the subsidence that formed the Yukon Flats basin. Till and others (2005) call the basin "a product of latest Cretaceous(?) and

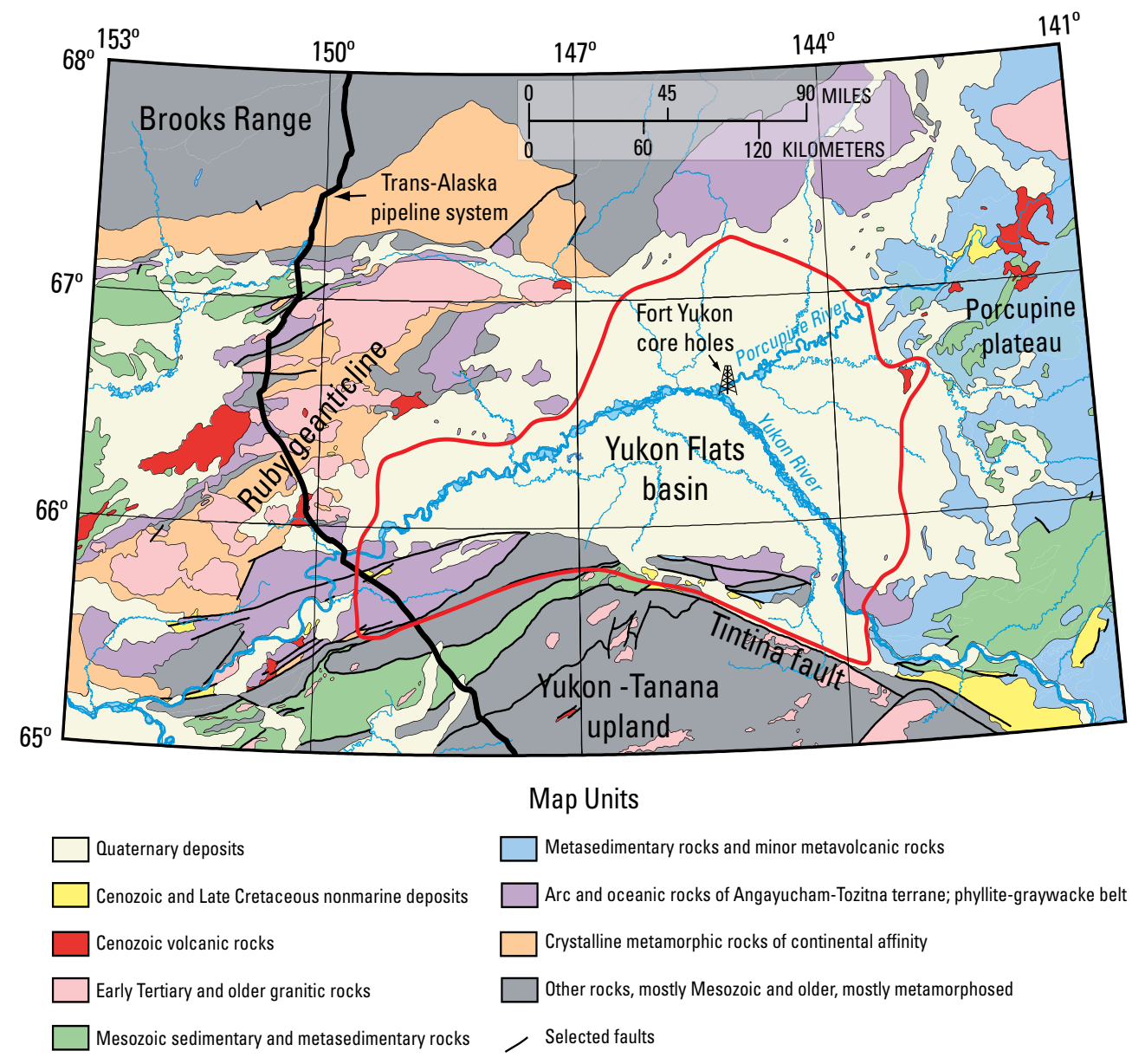

Figure 2. Generalized geologic map of the Yukon Flats region (simplified from Till and others, 2006). The red line indicates the approximate boundary of the Yukon Flats basin (Stanley and others, 2004). Base map credits are shown in figure 1. 
early Tertiary extension and right-lateral movement along the Tintina fault system." In contrast, Bradley and others (2003) relate early Tertiary basin subsidence and magmatism in interior Alaska to the mid-Paleocene to early Eocene subduction of an oceanic spreading center. Bradley and others (2003) propose that "extensional (or transtensional) basin subsidence was driven by the two subducting plates that each exerted different tractions on the upper plate." The timing of initial basin subsidence in our burial history models ranges from 70 to 60 million years before present $(\mathrm{Ma})$ and is intended to accommodate a range of possible basin-forming mechanisms.

\section{Yukon Flats Stratigraphy}

Seismic reflection, gravity, and magnetic surveys of Yukon Flats indicate the presence of low-density sedimentary strata in the basin with thicknesses up to 24,000 ft (Phillips and Saltus, 2005). On the basis of shallow core hole penetrations and by analogy with outcrops near Yukon Flats, these strata are thought to consist mainly of Upper Cretaceous(?) and Cenozoic nonmarine sedimentary rocks (Stanley and others, 2005). Coal, mudstone, and lacustrine shale in this sequence represent potential oil and gas source rocks. Volcanic rocks of Tertiary age are present in the uplands to the south, west, and northeast of Yukon Flats and may be present within the basin (figs. 2 and 3; Till and others, 2005, 2006).

Seismic reflection profiles of Yukon Flats show a prominent, basinwide horizon that marks a shift in the spacing and continuity of reflectors. In the deepest portion of the basin, the horizon occurs at a depth of about 9,000 ft. Subtle truncations of reflectors against this horizon suggest that, locally, it is an erosional unconformity. However, given our scant knowledge of the unconformity, we do not specify erosion or assign a time interval to it in the models. Rather, the unconformity marks a shift in the style of sedimentation corresponding to the change in character of the seismic reflectors. In the models, this shift is represented by a change in lithology and in sedimentation rate. The age of the unconformity may correspond to one of several pulses of regional deformation and uplift in central Alaska during the mid-Tertiary (Till and others, 2004, 2005). We assigned ages of $45 \mathrm{Ma}$ and $24 \mathrm{Ma}$ to the unconformity in our burial model scenarios to approximately bracket the suggested uplift interval.

The lithologies of the shallow units in our models were obtained from drill holes near Fort Yukon while lithologies of the deeper units were inferred from outcrops in the uplands that surround the basin. Ages assigned to our model stratigraphic units are also based on outcrop studies in the Yukon Flats region. Table 1 summarizes the lithologies and source

\section{WEST}

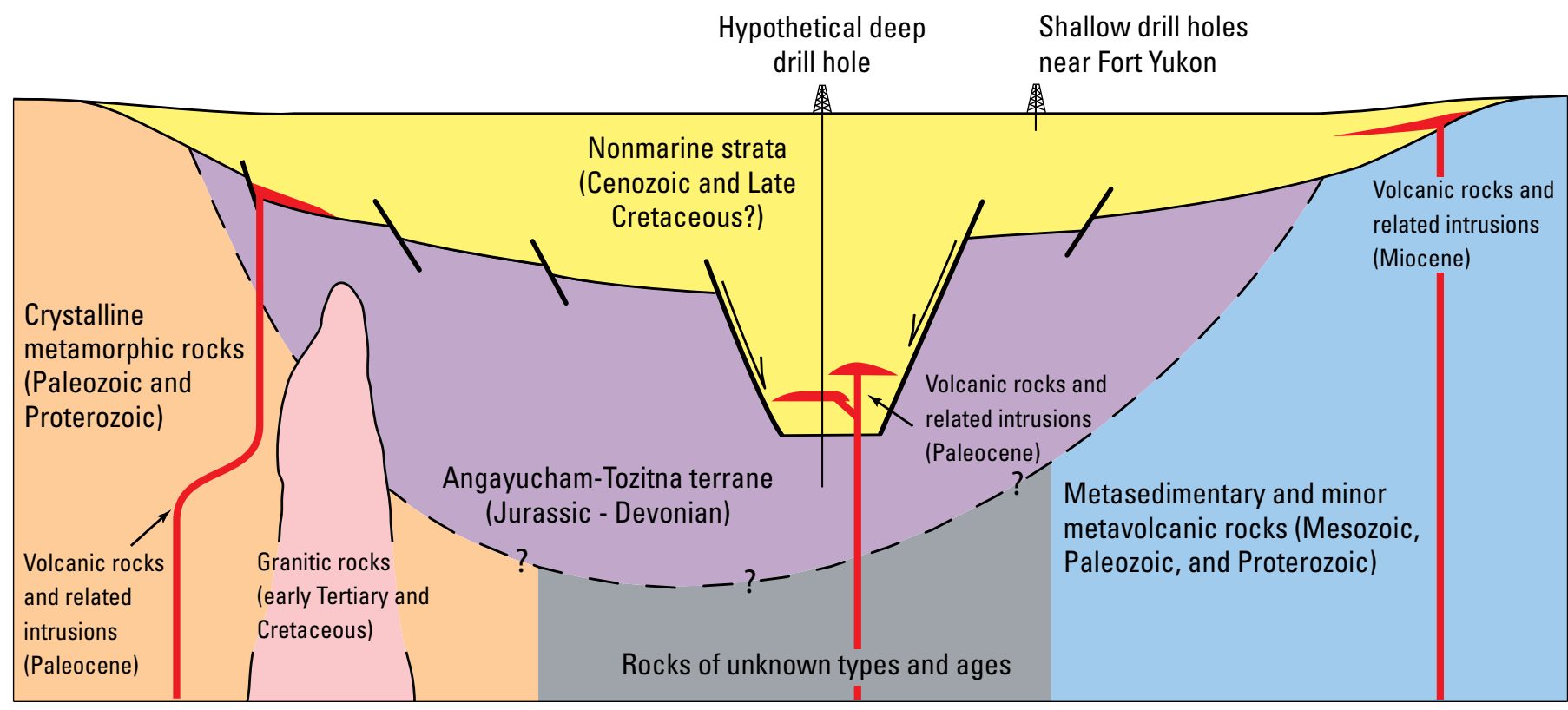

Figure 3. Schematic geologic cross section through the Yukon Flats basin. Well symbols indicate the locations of shallow core holes near Fort Yukon and of the hypothetical deep well on which our burial history models are based. Yukon Flats basin fill is composed of nonmarine sedimentary strata (shown in yellow) deposited in an extensional basin. Normal faults are indicated by heavy, solid lines. The boundary between the Angayucham-Tozitna terrane and deeper basement rocks (dashed line) is highly speculative and has been inferred from geophysical surveys. 
rock properties of the model units; ages of the model units are included in table 2.

The Yukon Flats basin rests unconformably on the Angayucham-Tozitna terrane, which was obducted onto the margin of arctic Alaska during the Jurassic (Till and others, 2005). The terrane is stratigraphically and structurally complex and consists mainly of oceanic sedimentary and igneous rocks of Devonian to Jurassic age (Till and others, 2005). In the uplands to the north of Yukon Flats, the unit reportedly includes small amounts of tasmanite, a combustible shale containing marine algal material of the genus Tasmanites, and a potential source rock for petroleum (see table 1 of Troutman and Stanley, 2003).

In the Porcupine plateau area to the east of Yukon Flats, the Angayucham-Tozitna terrane is structurally underlain by metasedimentary and minor metavolcanic units ranging from Mesozoic to Proterozoic in age. West of the Yukon Flats basin, the Ruby geanticline consists of Paleozoic and Proterozoic crystalline metamorphic rocks that are also structurally beneath the Angayucham-Tozitna terrane (figs. 2 and 3).

\section{Basin Models}

\section{Description of Geologic Scenarios}

Four burial history scenarios (1a, b and 2a, b) have been developed for a hypothetical well drilled through the deepest portion of the Yukon Flats basin (table 2). Thermal maturity, a function of temperature integrated over time, is calculated in one-dimensional models of the scenarios using BasinMod software (Platte River Associates, Inc.). The scenarios vary the thickness and timing of the Late Cretaceous(?) - Cenozoic model units and the timing of initial basin subsidence. In addition, each scenario was modeled with alternative timing of the mid-Tertiary unconformity, Eocene (45 Ma, scenarios 1a and 2a) and Oligocene (24 Ma, scenarios $1 \mathrm{~b}$ and $2 \mathrm{~b}$ ). The unconformity marks a shift in lithology and in sedimentation rate, but no erosion or duration is attributed to it in our models. Sedimentation rates are depicted graphically in the burial history figures discussed in the next section.

In all scenarios, the Angayucham-Tozitna terrane comprises the basal unit of the model, followed by a hiatus in deposition from Early Jurassic to Late Cretaceous or early Tertiary. In scenarios $1 \mathrm{a}$ and $1 \mathrm{~b}$, rapid basin subsidence begins at $60 \mathrm{Ma}$, consistent with the spreading ridge subduction hypothesis of Bradley and others (2003). Deposition of nonmarine sedimentary and volcanic rocks occurs during the Paleocene, and nonmarine sedimentary rocks are deposited during the remainder of the Cenozoic. In scenarios $2 a$ and $2 b$, basin subsidence begins at $70 \mathrm{Ma}$, prior to possible subduction of a spreading ridge. Late Cretaceous transtensional movement along the Tintina fault represents a possible mechanism for initial basin subsidence (Till and others, 2005). Nonmarine sedimentary rocks are deposited during the Late Cretaceous and Cenozoic (table 2).

\section{Thermal Parameters - Heat Flow, Thermal Conductivity, and Surface Temperature}

Heat-flow values of 70 to 90 milliwatts per square meter $\left(\mathrm{mW} / \mathrm{m}^{2}\right)$ characterize most of interior Alaska (Blackwell and Richards, 2004). Although relatively high, this heat-flow range is appropriate for young, extensional basins (Allen and Allen, 1990, fig. 9.18). In models of the Yukon Flats basin, we assign a heat-flow of $77 \mathrm{~mW} / \mathrm{m}^{2}$, constant since the onset

Table 1. Hypothetical lithologies and source rocks of the Yukon Flats basin.

[Colors in this table correspond to lithologies of the model stratigraphic units in table 2.]

\begin{tabular}{|c|c|c|}
\hline Stratigraphic unit & Lithology & Source rocks and kerogen types \\
\hline Alluvium & Sandstone and conglomerate (100\%) & \\
\hline $\begin{array}{l}\text { Nonmarine sedimentary rocks- } \\
\text { Upper unit }\end{array}$ & Mudstone $(80 \%)$, sandstone (15\%), coal (5\%) & Coal and mudstone: types II and III kerogen \\
\hline \multicolumn{3}{|l|}{ Unconformity } \\
\hline $\begin{array}{l}\text { Nonmarine sedimentary rocks- } \\
\text { Lower unit }\end{array}$ & $\begin{array}{l}\text { Sandstone and conglomerate }(40 \%) \text {, mudstone }(40 \%) \text {, } \\
\text { lacustrine shale }(15 \%) \text {, coal }(5 \%)\end{array}$ & $\begin{array}{l}\text { Coal and mudstone: types II and III kerogen; } \\
\text { lacustrine shale (possibly analogous to Green } \\
\text { River Formation): type I kerogen }\end{array}$ \\
\hline $\begin{array}{l}\text { Nonmarine sedimentary and } \\
\text { volcanic rocks }\end{array}$ & $\begin{array}{l}\text { Sandstone and conglomerate }(30 \%) \text {, mudstone }(30 \%) \text {, } \\
\text { basalt }(25 \%) \text {, lacustrine shale }(10 \%) \text {, coal }(5 \%)\end{array}$ & $\begin{array}{l}\text { Coal and mudstone: types II and III kerogen; } \\
\text { lacustrine shale (possibly analogous to Green } \\
\text { River Formation): type I kerogen }\end{array}$ \\
\hline \multicolumn{3}{|l|}{ Unconformity } \\
\hline Angayucham-Tozitna terrane & $\begin{array}{l}\text { Basalt and andesite }(49 \%) \text {, argillite }(20 \%) \text {, sandstone } \\
(20 \%) \text {, ultramafic rocks }(5 \%) \text {, chert }(5 \%) \text {, tasman- } \\
\text { ite }(1 \%)\end{array}$ & $\begin{array}{l}\text { Tasmanite (oil shale): type I and (or) type II } \\
\text { kerogen }\end{array}$ \\
\hline
\end{tabular}


Table 2. Model units, present day thicknesses, ages, and simplified lithologic compositions used in the Yukon Flats models.

[Colors in this table correspond to lithologies of the model stratigraphic units in table 1. Ma, million years before present]

\begin{tabular}{|c|c|c|c|c|c|c|c|c|}
\hline \multirow[t]{2}{*}{ Model unit name } & \multirow{2}{*}{$\begin{array}{c}\text { Model unit } \\
\text { thickness (feet) }\end{array}$} & \multicolumn{2}{|c|}{ Model age (Ma) } & \multicolumn{5}{|c|}{ Model lithologic fractions (percent) } \\
\hline & & Top & Bottom & Sandstone & Siltstone & Shale & Kerogen & Igneous \\
\hline \multicolumn{9}{|c|}{ Scenario 1a } \\
\hline Quaternary alluvium & 1,000 & 0 & 2 & 100 & 0 & 0 & 0 & 0 \\
\hline $\begin{array}{l}\text { Pliocene-middle } \\
\text { Eocene }\end{array}$ & 8,000 & 2 & 45 & 15 & 0 & 80 & 5 & 0 \\
\hline Unconformity & & 45 & 45 & & & & & \\
\hline middle-early Eocene & 7,000 & 45 & 55 & 40 & 0 & 55 & 5 & 0 \\
\hline Paleocene & 8,000 & 55 & 60 & 30 & 0 & 40 & 5 & 25 \\
\hline Unconformity & & 60 & 180 & & & & & \\
\hline $\begin{array}{l}\text { Angayucham-Tozitna } \\
\text { terrane }\end{array}$ & 4,000 & 180 & 408 & 25 & 20 & 0 & 1 & 54 \\
\hline \multicolumn{9}{|c|}{ Scenario 1b } \\
\hline Quaternary alluvium & 1,000 & 0 & 2 & 100 & 0 & 0 & 0 & 0 \\
\hline Pliocene-Miocene & 8,000 & 2 & 24 & 15 & 0 & 80 & 5 & 0 \\
\hline Unconformity & & 24 & 24 & & & & & \\
\hline Oligocene-Eocene & 7,000 & 24 & 55 & 40 & 0 & 55 & 5 & 0 \\
\hline Paleocene & 8,000 & 55 & 60 & 30 & 0 & 40 & 5 & 25 \\
\hline Unconformity & & 60 & 180 & & & & & \\
\hline $\begin{array}{l}\text { Angayucham-Tozitna } \\
\text { terrane }\end{array}$ & 4,000 & 180 & 408 & 25 & 20 & 0 & 1 & 54 \\
\hline \multicolumn{9}{|c|}{ Scenario 2a } \\
\hline Quaternary alluvium & 1,000 & 0 & 2 & 100 & 0 & 0 & 0 & 0 \\
\hline $\begin{array}{l}\text { Pliocene-middle } \\
\text { Eocene }\end{array}$ & 8,000 & 2 & 45 & 15 & 0 & 80 & 5 & 0 \\
\hline Unconformity & & 45 & 45 & & & & & \\
\hline $\begin{array}{l}\text { middle Eocene-Late } \\
\text { Cretaceous }\end{array}$ & 15,000 & 45 & 70 & 40 & 0 & 55 & 5 & 0 \\
\hline Unconformity & & 70 & 180 & & & & & \\
\hline $\begin{array}{l}\text { Angayucham-Tozitna } \\
\text { terrane }\end{array}$ & 4,000 & 180 & 408 & 25 & 20 & 0 & 1 & 54 \\
\hline \multicolumn{9}{|c|}{ Scenario 2b } \\
\hline Quaternary alluvium & 1,000 & 0 & 2 & 100 & 0 & 0 & 0 & 0 \\
\hline Pliocene-Miocene & 8,000 & 2 & 24 & 15 & 0 & 80 & 5 & 0 \\
\hline Unconformity & & 24 & 24 & & & & & \\
\hline $\begin{array}{l}\text { Oligocene-Late } \\
\text { Cretaceous }\end{array}$ & 15,000 & 24 & 70 & 40 & 0 & 55 & 5 & 0 \\
\hline Unconformity & & 70 & 180 & & & & & \\
\hline $\begin{array}{l}\text { Angayucham-Tozitna } \\
\text { terrane }\end{array}$ & 4,000 & 180 & 408 & 25 & 20 & 0 & 1 & 54 \\
\hline
\end{tabular}


of extension. A number of hot springs with temperatures $>40$ degrees Celsius $\left({ }^{\circ} \mathrm{C}\right)$ have been mapped at the Yukon Flats basin margins (Blackwell and Richards, 2004), consistent with ground-water flow along open fractures and suggesting that faults may still be active. For comparison with Yukon Flats, the mean heat-flow for continental North America is $54.4 \mathrm{~mW} / \mathrm{m}^{2}$ (Sclater and others, 1980; Allen and Allen, 1990, table 2.2), and on Alaska's North Slope, a foreland basin, most heat-flows range from 45 to $65 \mathrm{~mW} / \mathrm{m}^{2}$.

The thermal maturities calculated in our one-dimensional basin models are based on temperature as a function of burial depth and through time. Temperature gradient with depth $(\Delta T / \Delta Z)$ at steady state is related to heat-flow $(Q)$ and bulk thermal conductivity of the rock units $(\lambda)$ as follows: $\Delta T / \Delta Z$ $=Q / \lambda$ (for example, Carslaw and Jaeger, 1959, ch. 3, eq. 1, p. 92). The combined parameter $(Q / \lambda)$ is equivalent to thermal gradient. The bulk (rock + water) thermal conductivities of the model units vary with lithology, as well as with the effects of burial, compaction, porosity loss, and increasing temperature. Figure 4 shows bulk thermal conductivity versus depth for scenario 1a; profiles for the other scenarios are similar. An average value of $1.67 \mathrm{~mW} / \mathrm{m}^{2}$ reflects the high shale content of the model lithologies (tables 1 and 2). When combined with heat-flow $\left(77 \mathrm{~mW} / \mathrm{m}^{2}\right)$, the resulting thermal gradient averaged over the stratigraphic column is $46^{\circ} \mathrm{C}$ per kilometer $(\mathrm{km})$.

While there is some information on heat-flow available from the literature, we lack any data on thermal conductivities of the rocks at depth in the basin. To address uncertainties in both heat-flow and conductivity in a simplified fashion, we ran additional simulations that varied heat-flow from 54 to $100 \mathrm{~mW} / \mathrm{m}^{2}\left(77 \mathrm{~mW} / \mathrm{m}^{2} \pm 30\right.$ percent, \%), holding thermal conductivity constant. This approach gave approximately the same results as varying thermal conductivity $(\lambda)$ by $\pm 30 \%$ with heat-flow $(Q)$ constant. The results are discussed below.

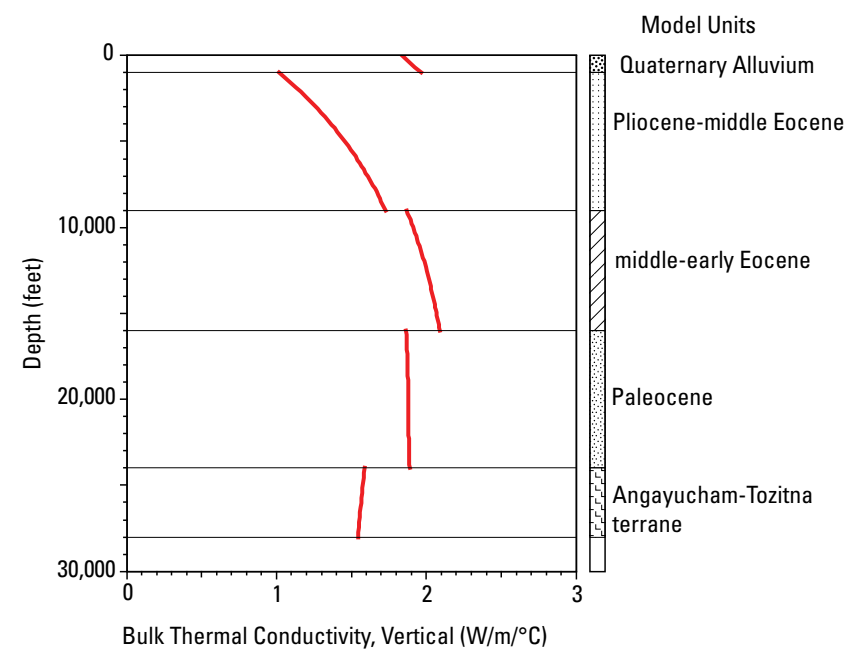

Figure 4. Bulk (rock + water) vertical thermal conductivity versus depth, shown for scenario 1a; values are similar in the other scenarios. Thermal conductivities vary with lithology and with burial depth due to changes in porosity and temperature. $\mathrm{W} / \mathrm{m} /{ }^{\circ} \mathrm{C}$, watts per meter per degree Celsius.
Surface temperature is the final thermal parameter specified in the models. A present-day surface temperature of $-6.8^{\circ} \mathrm{C}$ was assumed, consistent with the mean annual temperature in Fairbanks and with temperature measurements from a shallow well near Fort Yukon. Paleosurface temperatures used in the models were obtained from a study by Wygrala (1989) that compiled mean annual surface temperature and its variation with latitude through time (fig. 5).

\section{Vitrinite Reflectance and Thermal Maturity}

Throughout this study, thermal maturity is defined in terms of vitrinite reflectance, which provides a measure of thermal stress, that is, temperature integrated over time. Vitrinite reflectance $\left(R_{0}\right)$ is perhaps the most commonly measured and widely quoted thermal maturity indicator and serves as a de facto reference scale for the thermal maturity of organic matter. $R_{0}$ is readily calculated in numerical models (for example, Sweeney and Burnham, 1990), and $R_{0}$ values can be predicted for strata throughout the model domain and through time. $R_{0}$ increases with both temperature and time, although temperature generally plays the dominant role in determining maturity. In general, $\mathrm{R}_{\mathrm{o}}$ values increase rapidly with increasing temperature above a threshold of $\sim 60^{\circ} \mathrm{C}$.

An $R_{0}$ value of $0.6 \%$ is commonly used to mark the onset of oil generation in oil-prone source rocks. The transition from oil generation to the cracking of oil to form gas is somewhat more arbitrary, and $\mathrm{R}_{\mathrm{o}}$ values for the transition range from approximately 1.2 to $1.4 \%$ in the literature. The terms "oil window" and "gas window," respectively, refer to the thermal maturity ranges in which predominantly oil and predominantly gas are generated. In this study, we define the oil window to be $0.6 \% \leq \mathrm{R}_{0}<1.4 \%$, and the gas window to be $1.4 \% \leq \mathrm{R}_{0} \leq 3.0 \%$, consistent with Kübler and Jaboyedoff (2000, fig. 8). These $\mathrm{R}_{\mathrm{O}}$ ranges serve as general indicators of the conditions at which oil and thermogenic gas could be expected to form and are appropriate in frontier areas such as Yukon Flats, where information on actual kerogen types and their kinetics is not available.

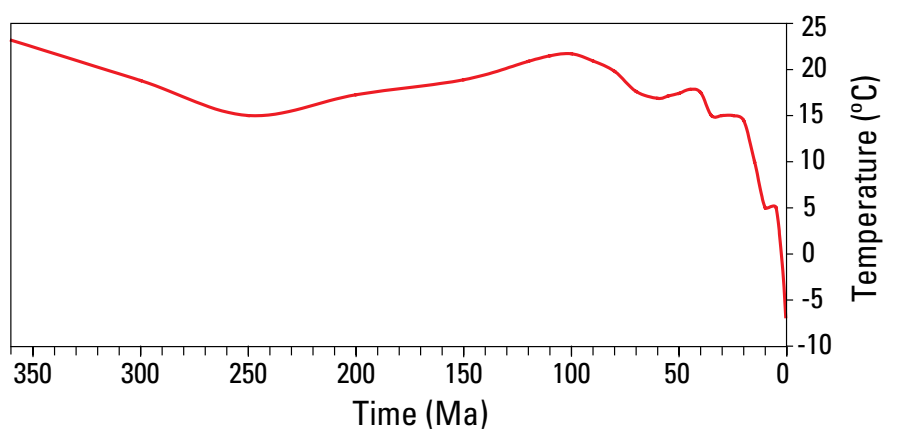

Figure 5. Mean annual surface temperature through time at a latitude of $66.5^{\circ} \mathrm{N}$. (based on Wygrala, 1989). These temperatures were used in the Yukon Flats burial and thermal history models. $\mathrm{Ma}$, million years before present; ${ }^{\circ} \mathrm{C}$, degrees Celsius. 


\section{Model Results}

Burial histories and thermal maturities for the four modeled scenarios are illustrated in figures $6 A, B$ and $7 A, B$. Total basin subsidence includes a component of tectonic subsidence in addition to subsidence resulting from sediment loading and compaction during burial (Allen and Allen, 1990). Dashed lines indicate the amount of accommodation space created by tectonic subsidence.

The green and red color bands represent the oil and gas windows, defined as $0.6 \% \leq \mathrm{R}_{\mathrm{o}}<1.4 \%$, and $1.4 \% \leq \mathrm{R}_{\mathrm{o}} \leq 3.0 \%$, respectively, and are based on $\mathrm{R}_{\mathrm{O}}$ values calculated for each model. Few data are available to constrain the calculations. In a core hole at Fort Yukon, mean $R_{O}$ values of 0.21 to $0.27 \%$ were measured in lignite-bearing strata of Miocene age at depths of 1,066 to 1,279 ft (Mark J. Pawlewicz, U.S. Geological Survey, written commun., 2001). In all of the models, these $\mathrm{R}_{\mathrm{o}}$ data bracket the model-calculated values; results are shown for scenario la (fig. 8).

\section{Scenarios 1a and 1b}

In scenario $1 \mathrm{a}$, basin subsidence begins at $60 \mathrm{Ma}$ accompanied by rapid sediment deposition represented by the Paleocene and middle-early Eocene model units. The mid-Tertiary unconformity is assumed to have formed at $45 \mathrm{Ma}$. The present-day top of the oil window, defined as an $\mathrm{R}_{0}$ of $0.6 \%$, is at a depth of 5,817 ft in the Pliocene-middle Eocene unit. The oil window extends over 4,603 ft and the gas window over an additional 4,949 $\mathrm{ft}$ of Cenozoic strata that are assumed to contain hydrocarbon source rocks (fig. 6A, table 1).

In scenario $1 \mathrm{~b}$, the assumed age of the mid-Tertiary unconformity is $24 \mathrm{Ma}$, but the lithologies and thicknesses remain unchanged from scenario 1a (table 2). Despite marked differences in Tertiary sedimentation rates, present-day thermal maturities are similar in scenarios $1 \mathrm{a}$ and $1 \mathrm{~b}$. The depth to an $R_{0}$ of $0.6 \%$ in scenario $1 \mathrm{~b}$ is $6,058 \mathrm{ft}$ and the widths of oil and gas windows are 4,820 ft and $5,118 \mathrm{ft}$, respectively (fig. 6B).

\section{Scenarios $2 a$ and $\mathbf{2 b}$}

In these scenarios, basin subsidence and sedimentation begin at $70 \mathrm{Ma}$ during the Late Cretaceous. The mid-Tertiary unconformity is assumed to be at $45 \mathrm{Ma}$ and $24 \mathrm{Ma}$ in scenarios $2 \mathrm{a}$ and $\mathrm{b}$, respectively. The ages and lithologies of the two youngest model units in scenarios $2 \mathrm{a}$ and $2 \mathrm{~b}$ are the same as those of the corresponding units in scenarios $1 \mathrm{a}$ and $1 \mathrm{~b}$ (table 2). The present-day depths to the oil window in scenarios $2 \mathrm{a}$ and $2 \mathrm{~b}$, respectively, are $5,817 \mathrm{ft}$ and $6,056 \mathrm{ft}$, nearly identical to the depths in scenarios $1 \mathrm{a}$ and $1 \mathrm{~b}$. In addition, the widths of the oil and gas windows are nearly identical to the widths of the windows in scenarios $1 \mathrm{a}$ and $1 \mathrm{~b}$ (figs. $6 A, B$ and $7 A, B)$.

\section{Sensitivity Tests-Variation in Heat Flow}

To examine the effect of uncertainty in thermal parameters on thermal maturity, we allowed model heat flow to vary by as much as $\pm 30 \%$ of the base case $\left(77 \mathrm{~mW} / \mathrm{m}^{2}\right)$. This relatively wide heat-flow range $\left(54\right.$ to $\left.100 \mathrm{~mW} / \mathrm{m}^{2}\right)$ is intended to incorporate uncertainties in heat-flow as well as thermal conductivity for which we lack data (see discussion above).

Calculated $\mathrm{R}_{\mathrm{o}}$ values in scenario 1a were compared at the top of the middle-early Eocene unit. The original heat flow $\left(77 \mathrm{~mW} / \mathrm{m}^{2}\right)$ results in an $\mathrm{R}_{\mathrm{o}}$ of $1.3 \%$ at this horizon. The response of $\mathrm{R}_{\mathrm{o}}$ to increased or decreased heat-flow is shown in figure 9. At the low end of our heat-flow range, $54 \mathrm{~mW} / \mathrm{m}^{2}$, the base of the middle-early Eocene unit would have an $\mathrm{R}_{\mathrm{o}}$ of $0.65 \%$, barely into the oil generation window. At the high end of our heat-flow range, $100 \mathrm{~mW} / \mathrm{m}^{2}$, this horizon would be well into the gas window with a calculated $\mathrm{R}_{\mathrm{o}}$ of $1.85 \%$. Changes in the depth to the top of the oil window $\left(\mathrm{R}_{\mathrm{o}}=0.6 \%\right)$ as a function of heat-flow are shown in figure 10 .

\section{Summary and Conclusions}

Seismic, magnetic, and gravity surveys indicate the presence of a deep sedimentary basin beneath Yukon Flats. On the basis of analogy with outcrops around the margins of the basin and core from a shallow well near Fort Yukon, the basin appears to be filled by Late Cretaceous(?) and Tertiary sedimentary strata that include sandstone, mudstone, shale, and coal of nonmarine (fluvial and lacustrine) origin. In some other localities, such as Cook Inlet, Alaska, rocks of similar age, lithology, and origin contain commercial accumulations of oil and gas.

Burial and thermal history models for a hypothetical well in the deepest portion of the Yukon Flats basin (fig. 3) provide thermal maturity estimates for potential source rocks based on calculated $\mathrm{R}_{\mathrm{O}}$ values. Because geological information from the basin is scarce, four different geological scenarios were modeled to evaluate their implications for thermal history and petroleum generation. In scenarios $1 \mathrm{a}$ and $1 \mathrm{~b}$, initial basin subsidence is assumed to have begun during the Paleocene (60 Ma), consistent with the spreading ridge hypothesis of Bradley and others (2003). Subsidence in scenarios $2 \mathrm{a}$ and $2 \mathrm{~b}$ is assumed to have begun during the Late Cretaceous (70 $\mathrm{Ma}$ ), during an episode of transtension along the right-lateral Tintina fault.

In terms of thermal maturity, geological conditions in the Yukon Flats basin appear favorable for the occurrence of oil and gas. Despite differences in the timing of initial basin subsidence and sedimentation rates, the present-day thermal maturities in the four models are very similar (figs. 6 and 7). Potential source rocks entered the oil window between 57 and $64 \mathrm{Ma}$. Approximately 5,000 ft (4,602-4,819 ft) of potential source rock lies within the oil window with an additional approximately $5,000 \mathrm{ft}(4,948-5,118 \mathrm{ft})$ in the gas window at 

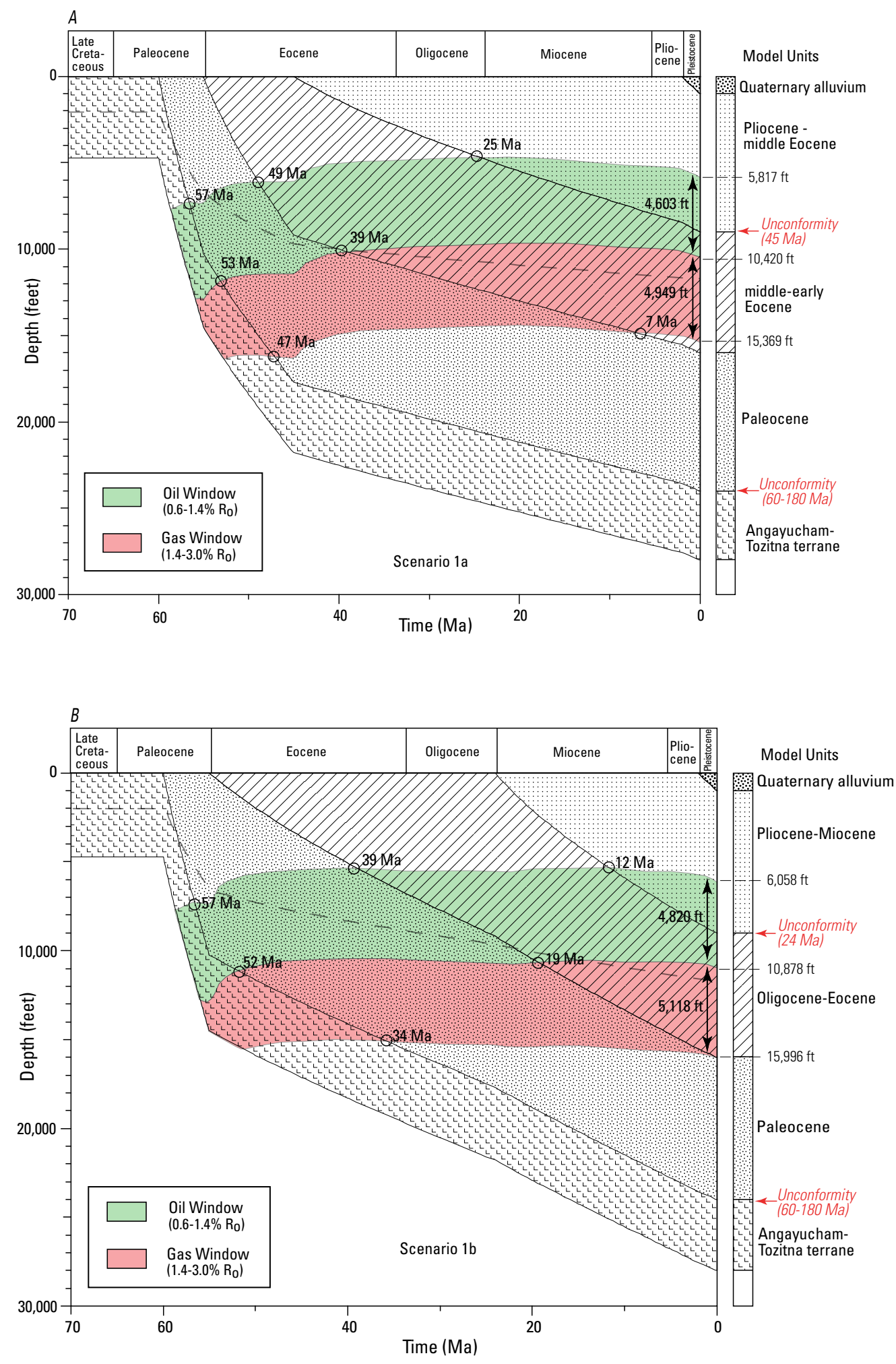

Figure 6. Burial histories for scenarios $1 \mathrm{a}$ and $1 \mathrm{~b}$, shown in parts $A$ and $B$, respectively. Burial depths of modeled stratigraphic units through time are shown for a hypothetical well in the deepest part of the Yukon Flats basin. The green and red bands represent the oil and gas windows, respectively; labels indicate times at which the window boundaries cross stratigraphic horizons. Dashed lines indicate the amount of accommodation space created by tectonic subsidence; total subsidence also includes the effects of sediment loading and compaction. Model input is summarized in table 2. $R_{0}$, vitrinite reflectance, in percent; $\mathrm{Ma}$, million years before present. 

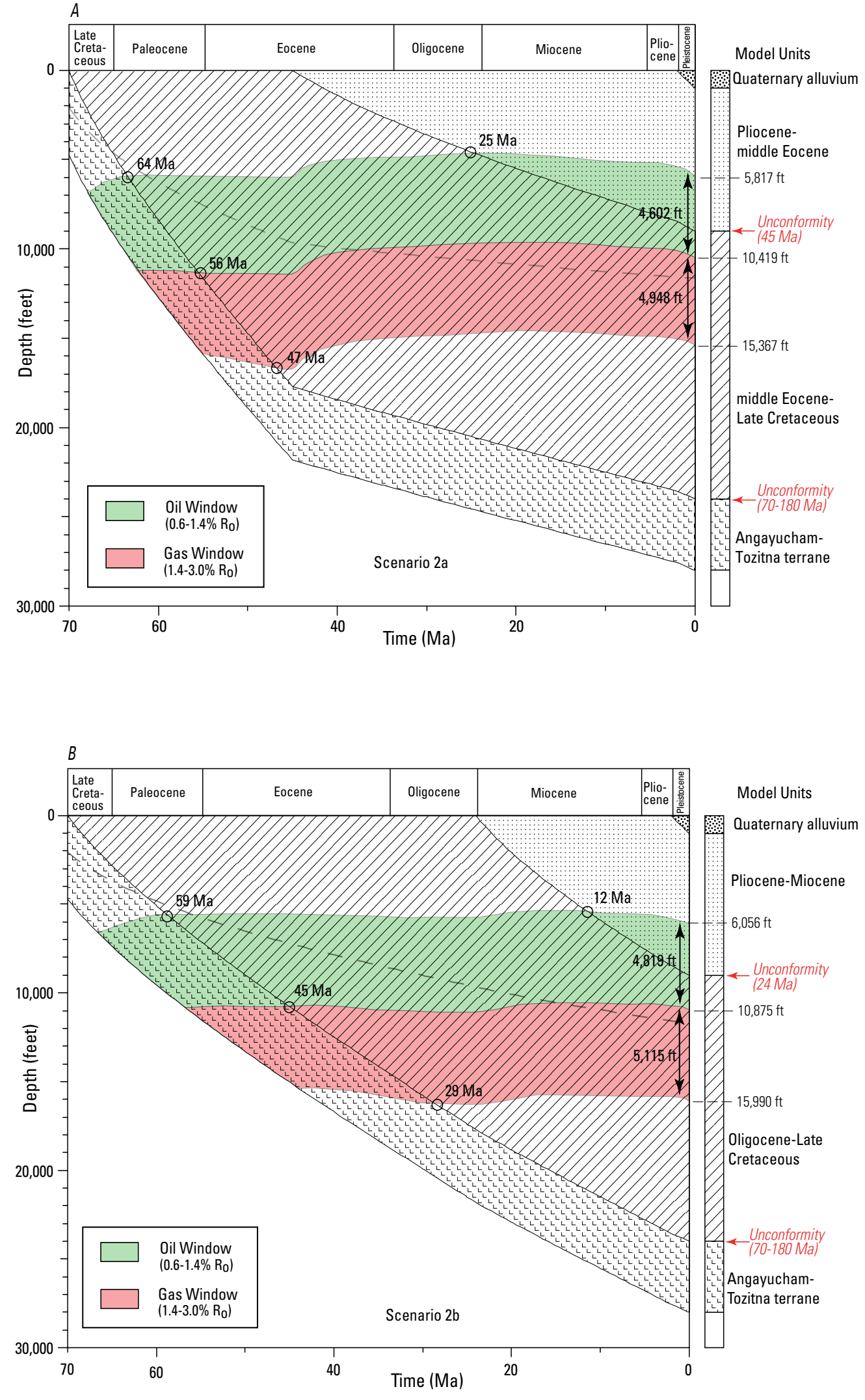

Figure 7. Burial histories for scenarios $2 a$ and $2 b$, shown in parts $A$ and $B$, respectively. Burial depths of modeled stratigraphic units through time are shown for a hypothetical well in the deepest part of the Yukon Flats basin. The green and red bands represent the oil and gas windows, respectively; labels indicate times at which the window boundaries cross stratigraphic horizons. Dashed lines indicate the amount of accommodation space created by tectonic subsidence; total subsidence also includes the effects of sediment loading and compaction. Model input is summarized in table $2 . R_{o}$ vitrinite reflectance, in percent; $\mathrm{Ma}$, million years before present. 
present day. Depths to the top of the oil window are approximately $6,000 \mathrm{ft}(5,817-6,058 \mathrm{ft})$.

To better understand the impact of uncertainty in the thermal parameters (heat-flow, thermal conductivity, and thermal gradient), we reran scenario 1a using a range of heat-flow values (figs. 9 and 10). A change in heat-flow of only $10 \%$ produces a significant change $(\sim 500 \mathrm{ft})$ in the depth to the top of the oil window. While the models synthesize our best educated guesses about the subsurface geology and thermal regime of Yukon Flats, figures 9 and 10 make clear that the results are best considered general conclusions rather than precise predictions.

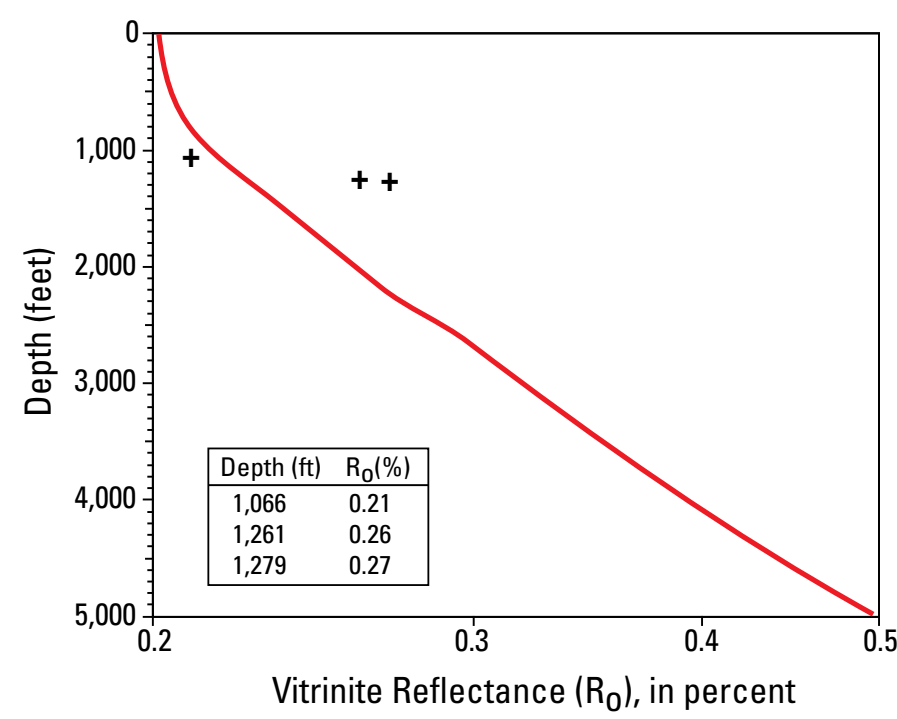

Figure 8. Model-calculated vitrinite reflectance $\left(R_{0}\right)$ values for scenario 1a (solid line). $\mathrm{R}_{\mathrm{o}}$ measurements (Mark J. Pawlewicz, U.S. Geological Survey, written commun., 2001) are plotted and listed in the inset table.

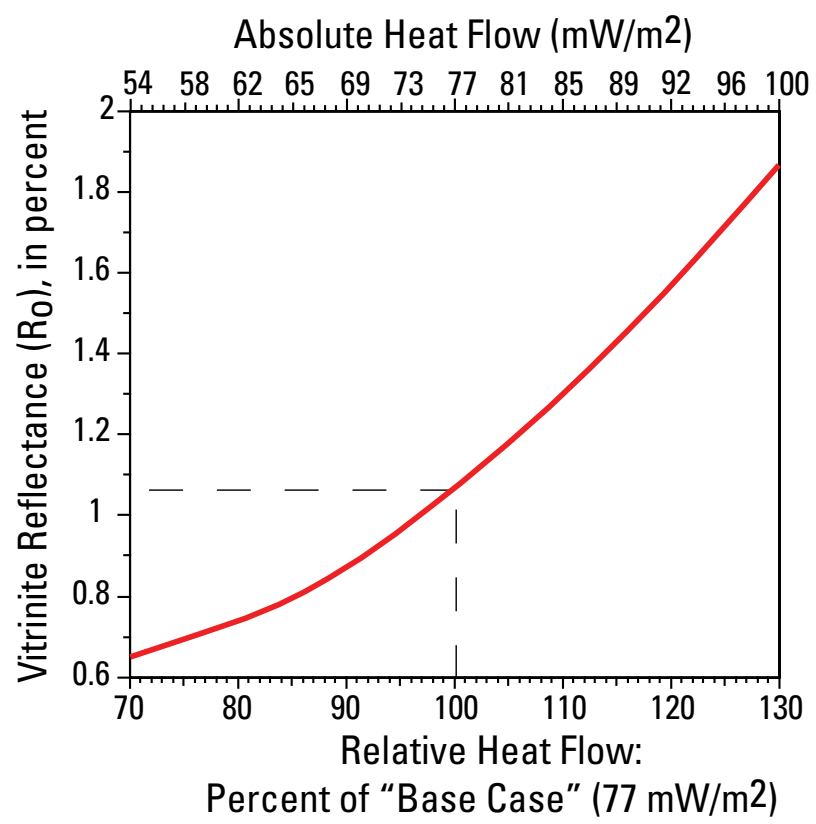

Figure 9. $R_{0}$ calculated for a range of heat flows at the top of the middle-early Eocene unit in scenario 1a. Heat flow ranges from 54 to 100 milliwatts per square meter $\left(\mathrm{mW} / \mathrm{m}^{2}\right)$ or \pm 30 percent $(\%)$ of the base case value, $77 \mathrm{~mW} / \mathrm{m}^{2}$.

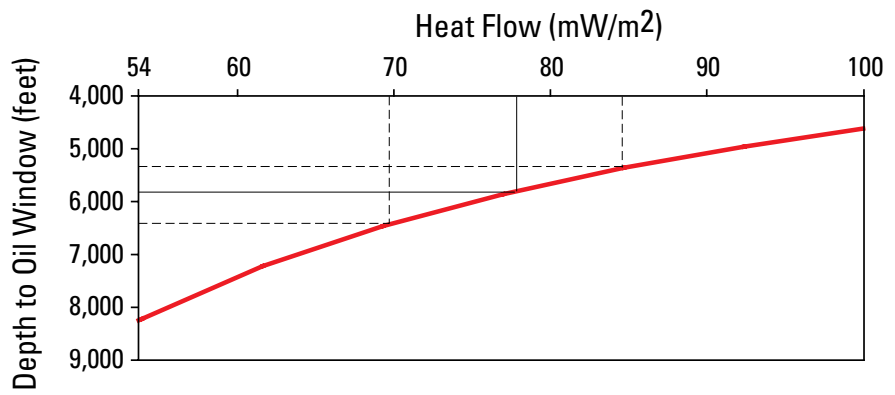

Figure 10. Depth to the top of the oil window shown for a range of heat-flow values in scenario 1a. The base case heat-flow value of 77 milliwatts per square meter $\left(\mathrm{mW} / \mathrm{m}^{2}\right)$ yields a depth to the oil window of 5,817 feet (ft). Dashed lines indicate heat-flow values 10 percent (\%) above and below $77 \mathrm{~mW} / \mathrm{m}^{2}$ and the resulting changes in depth to the oil window. 


\section{References Cited}

Ager, T.A., 1994, The U.S. Geological Survey Global Change Drilling Project at Fort Yukon, Alaska, 1994: unpublished report, $36 \mathrm{p}$.

Allen, P.A., and Allen, J.R., 1990, Basin analysis, principles and applications: Oxford, England, Blackwell Science, $451 \mathrm{p}$.

Barker, C.E., Clark, A.C., Clough, J.G., Maclean, E.A., Ogbe, D.O., Clautice, K.H., Weeks, E.P., and Fisk, R.F., 2005, Shallow coalbed gas assessment at Fort Yukon, Alaska: Geological Society of America, Cordilleran Section Meeting, San Jose, California, April 29-May 1, 2005, Abstracts with Programs, v. 37, no. 4, p. 95, available online at http://gsa.confex.com/gsa/2005CD/finalprogram/ abstract_85773.htm.

Blackwell, D.D., and Richards, M.C., 2004, Geothermal map of North America: Tulsa, OK, American Association of Petroleum Geologists, scale 1:6,500,000, 1 sheet.

Bradley, D.C., Kusky, T.M., Haeussler, P.J., Goldfarb, R.J., Miller, M.L., Dumoulin, J.A., Nelson, S.W., and Karl, S.M., 2003, Geologic signature of early Tertiary ridge subduction in Alaska, in Sisson, V.B., Roeske, S.M., and Pavlis, T.L., eds., Geology of a transpressional orogen developed during ridge-trench interaction along the North Pacific margin: Boulder, CO, Geological Society of America Special Paper 371, p. 19-49.

Carslaw, H.S., and Jaeger, J.C., 1959, Conduction of heat in solids, (2d ed.): Oxford, England, Oxford University Press, $510 \mathrm{p}$.

Finzel, E.S., Clough, J.G., Peapples, P.R., Reifenstuhl, R.R., and Wartes, M.A., 2006, Alaska Division of Geological \& Geophysical Surveys 2006 Energy-Resource Projects, Coalbed methane for rural energy: Alaska Division of Geological \& Geophysical Surveys, Department of Natural Resources, one sheet, available online at http://wwwdggs.dnr.state.ak.us/download/posters/Energy_ poster.pdf.

Kübler, B., and Jaboyedoff, M., 2000, Illite crystallinity: Contes Rendus de l'Académie des Sciences de Paris, Sciences de la Terre et des Planètes / Earth and Planetary Sciences, v. 331, p. 75-89.

Phillips, J.D., and Saltus, R.W., 2005, Thickness of sedimentary rocks in the Yukon Flats basin, east-central Alaska, as estimated using constrained iterative gravity inversion: Geological Society of America, Cordilleran Section Meeting, San Jose, CA, April 29-May 1, 2005, Abstracts with Programs, v. 37, no. 4, p. 94, available online at http://gsa.confex.com/gsa/2005CD/finalprogram/ abstract_85308.htm.
Rowan, E.L., and Stanley, R.G., 2005, Burial and thermal history models to evaluate hydrocarbon source rock maturity in the Yukon Flats basin, central Alaska: Geological Society of America, Cordilleran Section Meeting, San Jose, CA, April 29-May 1, 2005, Abstracts with Programs, v. 37, no. 4, p. 95 , available online at http://gsa.confex.com/gsa/2005CD/ finalprogram/abstract_85269.htm.

Sclater, J.G., Jaupart, C., and Galson, D., 1980, The heat flow through oceanic and continental crust and the heat loss of the earth: Reviews of Geophysics and Space Physics, v. 18, no. 1, p. 269-311.

Stanley, R.G., Ahlbrandt, T.S., Charpentier, R.R., Cook, T.A., Crews, J.M., Klett, T.R., Lillis, P.G., Morin, R.L., Phillips, J.D., Pollastro, R.M., Rowan, E.L., Saltus, R.W., Schenk, C.J., Simpson, M.K., Till, A.B., and Troutman, S.M., 2004, oil and gas assessment of Yukon Flats, east-central Alaska, 2004: U.S. Geological Survey Fact Sheet 2004-3121, 2 p., available online at http://pubs.usgs.gov/fs/2004/3121/.

Stanley, R.G., Till, A.B., Simpson, M.K., Schenk, C.J., Saltus, R.W., Rowan, E.L., Phillips, J.D., Morin, R.L., Lillis, P.G., and Crews, J.M., 2005, Assessment of undiscovered oil and gas resources in Yukon Flats, east-central Alaska: Geological Society of America, Cordilleran Section Meeting, San Jose, CA, April 29-May 1, 2005, Abstracts with Programs, v. 37, no. 4, p. 95 , available online at http://gsa.confex.com/ gsa/2005CD/finalprogram/abstract_85058.htm.

Sweeney, J.J., and Burnham, A.K., 1990, Evaluation of a simple model of vitrinite reflectance based on chemical kinetics: American Association of Petroleum Geologists Bulletin, v. 74, no. 10, p. 1559-1570.

Till, A.B., O’Sullivan, P.B., Bradley, D.C., and Roeske, S.M., 2004, Apatite fission track evidence for repeated Tertiary movement on the Tintina fault system, Alaska: Geological Society of America, Annual Meeting, Denver, CO, November 7-10, 2004, Abstracts with Programs, v. 36, no. 5, p. 512, available online at http:/gsa.confex.com/gsa/2004AM/ finalprogram/abstract_77395.htm.

Till, A.B., Stanley, R.G., O'Sullivan, P.B., Saltus, R.W., and Crews, J.M., 2005, Tectonic events leading to establishment of Yukon Flats basin, Alaska: Geological Society of America, Cordilleran Section Meeting, San Jose, CA, April 29-May 1, 2005, Abstracts with Programs, v. 37, no. 4, p. 94, available online at http://gsa.confex.com/gsa/2005CD/ finalprogram/abstract_85040.htm.

Till, A.B., Dumoulin, J.A., Phillips J.D., Stanley, R.G., and Crews, J.M., 2006, Digital data for the generalized bedrock geologic map, Yukon Flats region, east-central Alaska: U.S. Geological Survey Open-File Report 2006-1304, scale 1:500,000, available online at http://pubs.usgs.gov/ of $/ 2006 / 1304 /$. 
Troutman, S.M., and Stanley, R.G., 2003, Maps showing sedimentary basins, surface thermal maturity, and indications of petroleum in the Central Alaska Province: U.S. Geological Survey Miscellaneous Field Studies Map MF-2428, scale 1:2,500,000, available online at http://pubs.usgs.gov/ $\mathrm{mf} / 2003 / 2428 /$.

Williams, J.R., 1962, Geologic reconnaissance of the Yukon Flats district, Alaska: U.S. Geological Survey Bulletin 1111-H, p. 289-330.

Wygrala, B.P., 1989, Integrated study of an oil field in the southern Po basin, northern Italy: Jülich, Germany, Research Centre Jülich, Jul-Rep. 2313, ISSN 0366-0885, $217 \mathrm{p}$. 


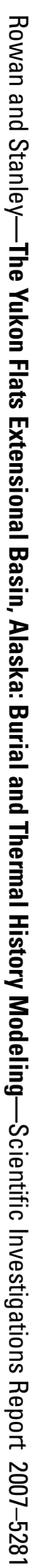

9 Printed on recycled paper 